10 Lipman RS, Covi L, Shapiro AK. The Hopkins symptom checklist (HSCL)-factors derived from the HSCL-90.J Affect Disord 1979;1:9-24.

11 Oxman TE, Dietrich AJ, Williams JW Jr, Kroenke K. A three-component model for reengineering systems for the treatment of depression in primary care. Psychosomatics 2002;43:441-50.

12 Kroenke K, Spitzer RL, Williams JB. The PHQ-9: validity of a brief depression severity measure. J Gen Intern Med 2001;16:606-13.

13 Kroenke K, Spitzer RL. The PHQ-9: a new depression diagnostic and severity measure. Psychiatr Annals 2002;32:509-21.

14 Spitzer RL, Williams JB, Kroenke K, Linzer M, deGruy FV 3rd, Hahn SR, et al. Utility of a new procedure for diagnosing mental disorders i primary care. The PRIME-MD 1000 study. JAMA 1994;272:1749-56.

15 Badamgarav E, Weingarten S, Henning J, Knight K, Hasselblad V, Gano A, et al. Effectiveness of disease management programs in depression: a systematic review. Am J Psychiatry 2003;160:2080-90.

16 Unutzer J, Katon W, Callahan CM, Williams JW Jr., Hunkeler E, Harpole I et al. Collaborative care management of late-life depression in the primary care setting: a randomized controlled trial. JAMA 2002;288:2836-45.

17 Eisenberg JM, Power EJ. Transforming insurance coverage into quality health care: voltage drops from potential to delivered quality. JAMA 2000;284:2100-7

18 Wells KB, Sherbourne C, Schoenbaum M, Duan N, Meredith L, Unutzer $\mathrm{J}$, et al. Impact of disseminating quality improvement programs for depression in managed primary care: a randomized controlled trial. JAMA 2000;283:212-20.

19 Bruce ML, Ten Have TR, Reynolds CF 3rd, Katz I, Schulberg HC, Mulsant $\mathrm{BH}$, et al. Reducing suicidal ideation and depressive symptoms in depressed older primary care patients: a randomized controlled trial. JAMA 2004;291:1081-91.

20 Katon W, Von Korff M, Lin E, Walker E, Simon GE, Bush T, et al. Collaborative management to achieve treatment guidelines. Impact on depression in primary care. JAMA 1995;273:1026-31.

21 Katon W, Von Korff M, Lin E, Simon G, Walker E, Unutzer J, et al. Stepped collaborative care for primary care patients with persistent symptoms of depression: a randomized trial. Arch Gen Psychiatry 1999;56:1109-15.

22 Simon GE, Von Korff M, Rutter C, Wagner E. Randomised trial of monitoring, feedback, and management of care by telephone to improve treattoring, feedback, and management of care by telephone to
ment of depression in primary care. BMJ 2000;320:550-4.

23 Hunkeler E, Meresman J, Hargreaves W, Fireman B, Berman W, Kirsch A, et al. Efficacy of nurse telehealth care and peer support in augmenting treatment of depression in primary care. Arch Fam Med 2000;9:700-8.

24 Hedrick SC, Chaney EF, Felker B, Liu CF, Hasenberg N, Heagerty P, et al. Effectiveness of collaborative care depression treatment in veterans' affairs primary care.J Gen Intern Med 2003;18:9-16.

(Accepted 19 July 2004)

doi $10.1136 /$ bmj.38219.481250.55

\title{
Commentary: Can care management enhance integration of primary and specialty care?
}

Michael Von Korff

Dietrich et al report a randomised controlled trial in which community practices implemented enhanced care for depressive illness. ${ }^{1}$ The programme was a quality improvement initiative of the participating healthcare organisations, not a stand alone intervention provided by the researchers. Key elements included telephone follow up of patients by a care manager, support of the care manager and the primary care clinician by a psychiatrist, and increased attention to patient education and goal setting by the primary care clinician. The magnitude of benefits was comparable to those of some previous effectiveness trials in which interventions were delivered by researchers. ${ }^{2}$ On completion, the organisational changes were extended to additional practices in the participating organisations.

Evidence that depression outcomes can be improved through systematic changes in delivery of care is now compelling. ${ }^{23}$ This study shows that community practices are able to implement and sustain improvements when offered a standardised care management programme and adequate support. Other chronic conditions that would benefit from such programmes include congestive heart failure, diabetes, and asthma.

As healthcare organisations consider implementing care management programmes, this study highlights three key points: the programme was standardised, but implementation was customised to each setting by the organisations; the care manager-a centralised resource not located in the primary care clinic-managed patients in collaboration with the clinician, who retained overall responsibility for patient care; a psychiatrist supervised the care manager, provided guidance to the clinician through the care manager, and advised the clinician directly as needed.

As a package, the introduction of a care management programme facilitated key changes in how patients, allied health professionals, clinicians, and specialists worked together to improve patient outcomes. By serving as a communication link, care managers can potentially bridge the ever widening gap in coordination of care between clinicians and specialists. ${ }^{4}$ In an era when technological progress has accelerated medical specialisation, ageing populations with multiple chronic conditions need integration of health care more than ever. Primary care clinicians will either embrace new ways of integrating care for their patients or continue to struggle with the onslaught of too many patients, seen in too little time, with seemingly disparate and disconnected needs. By enhancing communication and follow up, care managers may play a vital part in enhancing continuity of care, efficiently integrating the roles of the specialist and the primary care clinician.

Whether and how care management will be implemented on a mass basis is not settled. Should each major disease have its own care manager? Programmes of proved effectiveness have typically targeted individual chronic conditions, but this may not be the best path to integrating care for patients with multiple chronic conditions. It is heartening to learn that a centralised care management programme for depression, linked to primary care, could be successfully implemented and sustained in diverse community practices, but whether and how care management will be integrated into routine practice for the range of conditions that might benefit from enhanced follow up and coordination of care remains an open and critically important issue.

Competing interests: MVK gave an invited lecture on pain and depression at the European Society of Psychosomatic Research with support from Eli Lilly.

1 Dietrich A, Oxman TE, Williams JW, Schulberg HC, Bruce ML, Lee PW, et al. Re-engineering systems for the treatment of depression in primary care: cluster randomised controlled trial. BMJ 2004;329:602-5.

2 Gilbody S, Whitty P, Grimshaw J, Thomas R. Educational and organizational interventions to improve the management of depression in primary care: a systematic review. JAMA 2003;289:3145-51.

3 Von Korff M, Goldberg D. Improving outcomes in depression. BMJ 2001;323:948-9.

4 Katon W, Von Korff M, Lin E, Simon G. Rethinking practitioner roles in chronic illness: the specialist, primary care physician, and the practice nurse. Gen Hosp Psychiatry 2001;23:138-44.
Center for Health Studies, Group Health Cooperative 1730 Minor Avenue, Seattle, WA 98101, USA

Michael Von Korff senior investigator vonkorff.m@ghc.org 